TITLE:

\title{
Prefrontal hypofunction in patients with intractable mesial temporal lobe epilepsy(Abstract_要旨)
}

\author{
$\operatorname{AUTHOR}(\mathrm{S})$ : \\ Takaya, Shigetoshi
}

\section{CITATION:}

Takaya, Shigetoshi. Prefrontal hypofunction in patients with intractable mesial temporal lobe epilepsy. 京都大学, 2006, 博士(医学)

ISSUE DATE:

2006-11-24

URL:

http://hdl.handle.net/2433/135641

RIGHT: 


\begin{tabular}{|c|c|}
\hline 氏 & $\begin{array}{llll}\text { 吘 } & \text { 屋 } & \text { 战 } & \text { 利 }\end{array}$ \\
\hline 学位(専攻分野) & 博 士 (医 学) \\
\hline 学位記番号 & 医 博 第 3021 号 \\
\hline 学位授与の日付 & 平成 18 年 11 月 24 日 \\
\hline 学位授与の要件 & 学位規則第 4 条第 1 項該当 \\
\hline 研究科・専攻 & 医学研究科脳統御医科学系専攻 \\
\hline 学位論文題目 & $\begin{array}{l}\text { Prefrontal hypofunction in patients with intractable mesial temporal } \\
\text { lobe epilepsy } \\
\text { (難治性内側側頭葉てんかん患者に扔ける前頭前野機能低下) }\end{array}$ \\
\hline
\end{tabular}

論文調查委員教授高橋良輔教授河野憲二教授林拓二

\section{論文内容 の 要旨}

$<$ 背景 $>$

内側側頭葉てんかん患者における脳機能異常は, 側頭葉にとどまらず前頭葉にも存在することが神経心理検査や神経機能 画像検査を用いた先行研究により示されている。しかし，その病態生理や臨床症状との関わりについては不明な部分が多い。 当研究では，てんかん原性が高度であるほど，てんかん焦点領域を超えた広範な大脳皮質の機能異常を引き起こすとの仮定 の元に，内側側頭葉てんかん難治群と易治群の神経心理検査および脳ブドウ糖代謝を比較することで，高度なてんかん原性 が前頭前野機能に及ぼす影響について調べた。

$<$ 方法 $>$

対象は臨床的に確定診断された内側側頭葉てんかん患者22名。脳波及び核磁気共鳴画像（MRI）の結果により病側が確 定している者のみを対象とした。身体学的所見に異常の認められる者，MRI で内側側頭葉以外に有意な萎縮や病変を認め る者，現在及び過去において他の中枢神経疾患罹患の経験のある者は除外した。神経心理検査および脳ブドウ糖代謝につい て，薬剤抵抗性難治性内側側頭葉てんかん患者11名（難治群）と薬凨により発作が比較的良好にコントロールされている易 治性内側側頭葉てんかん患者10名 (易治群) を比較した。両群で年齢・性別・教育年数・知能・病側をマッチさせている。

認知機能検査は，ウエクスラー成人知能検査，ウエクスラー記銘力検査，改訂版ウィスコンシン・カード分類テスト (MWCST), trail making テスト, 2 and 7 テスト,レーブン色彩マトリックス検查を施行した。脳ブドウ糖代謝は,

$\left[{ }^{18} \mathrm{~F}\right]$ - fluorodeoxyglucose を静脈注射した後にポジトロン断層撮影法（positron emission tomography，PET）を用いて測 定した。脳ブドウ糖代謝の群間比較は, 解剖学的標準化によりボクセルごとに検討を行う方法（voxel-wise 解析）と，各 被検者の解剖学的構造をもとに関心領域を設定する方法（ROI 解析）を用いた。また, MWCSTの保続数と各領域のブド ウ糖代謝との相関を検討した。

$<$ 結果>

神経心理検査では, 難治グループは易治グループに比ベてセット・シフティング能力を反映すると考えられる MWCST における保続数が有意に多かった。記憶を含むその他の神経心理検査においては成績に有意差は認められなかった。難治グ ループは易治グループに比べて，両側前頭前野（病側>健側）のブドウ糖代謝低下が認められた。側頭葉のブドウ糖代謝に は両群で有意差を認めなかった。MWCSTにおける保続数は両側前頭前野のブドウ糖代謝と有意な相関が認められた。

<考察〉

内側側頭葉てんかんにおける高度のてんかん原性は，前頭前野のブドウ糖代謝低下や同部位の機能低下に由来すると考え られるセット・シフティング能力の低下を引き起こす。内側側頭葉のてんかん焦点における高頻度のてんかん活動が，投射 線維を経由して前頭前野に影響を及ぼすことで，遠隔領域の機能低下が引き起こされているものと推定される。 
難治性内側側頭葉てんかん患者における脳機能異常は，発作焦点の存在する側頭葉にとどまらず遠隔領域にも広がってい る。しかし，その病態生理や臨床症状とのかかわりについては不明な部分が多い。本研究では，高度なてんかん原性がてん かん焦点領域を超えた広範な大脳皮質の機能異常を引き起こすとの仮定の元に，内側側頭葉てんかん難治群と易治群の神経 心理検查抢よび脳ブドウ糖代謝を比較した。脳ブドウ糖代謝の測定にはポジトロン断層撮影法（FDG-PET）を用いた。 その結果, 難治群では易治群に比べて，七ット・シフティング能力を反映すると考えられているウィスコンシン・カードソ ーティングテストに扔ける保続数が有意に多く，また両側前頭前野のブドウ糖代謝低下も認められた。ブドウ糖代謝低下が 認められたのは，いずれもてんかん発作焦点の周辺領域と直接の線維連絡が想定されている部位であった。ウイスコンシン ・カードソーティングテストの保続数は両側前頭前野のブドウ糖代謝との間に有意な相関を認めた。これらの結果により, 内側側頭葉てんかんに㧍ける高度のてんかん原性は, 前頭前野のブドウ糖代謝低下や同部位の機能低下に由来する認知能力 の低下を引き起こすことが明らかになった。これらの機能低下は，内側側頭葉のてんかん発作焦点に掞ける高頻度のてんか ん活動が投射線維を経由して遠隔領域である前頭前野に影響を及ぼすことで惹起されるものと推察される。

以上の研究は，難治性内側側頭葉てんかん患者における認知機能低下の病態解明に貢献し，部分てんかんにおける広範な 脳機能異常に関する今後の研究に寄与するところが多い。

したがって，本論文は博士 (医学) の学位論文として価値のあるものと認める。

なお，本学位授与申請者は，平成18年10月 3 日実施の論文内容とそれに関連した諮問を受け，合格と認められたものであ る。 